\title{
The End of Cognition?
}

\author{
Phil Turner \\ Centre for Interaction Design \\ School of Computing, Napier University, Edinburgh \\ +44 (131) 4552700 \\ p.turner@napier.ac.uk
}

\begin{abstract}
Cognition has long been a central conceptual pillar for humancomputer interaction (HCI) but with the current emphasis on interaction design and user experience, this position may now be in doubt.
\end{abstract}

This workshop considers whether cognition still has relevance for the "post experience" generation.

\section{Categories and Subject Descriptors}

H5.m Information interfaces and presentations (e.g. HCI): Miscellaneous.

\section{General Terms}

Theory.

\section{Keywords}

Cognition, "Second Wave HCI".

\section{INTRODUCTION}

Carroll [1] in the introduction to his edited volume HCI Models, Theories and Frameworks notes that, "the initial vision of HCI as an applied science was to bring cognitive-science methods and theories to bear on software development. Most ambitiously, it was hoped that cognitive-science theory could provide substantive guidance at very early stages of the software development process." What Carroll has described as the "golden age of $\mathrm{HCI}$ " saw this come to fruition. Human computer interaction (HCI) has successfully developed numerous such methods which have ranged from model-based design approaches [2] to the use of formal methods [3]. Cognitive models and psychologically-plausible engineering models of human behaviour have also been derived [4] [5] [6] which, to a greater or lesser extent, have proved to be able to model the behaviour of people using interactive systems and devices. Some of these have even proved to be of practical value [7].

Add to this cognitive work analysis [8], cognitive ergonomics [9] and cognitive engineering [10] and the importance of cognition in all things interactive becomes apparent. Cognition has also given us metaphor, mental models and guidelines urging us to, for example, respect the constraints of memory by designing for recognition not recall [11]. And where would the

(C), Phil Turner, 2007 Published by the British

Computer Society Volume 2 Proceedings of the 21 st BCS HCI Group Conference HCI 2007, 3-7 September 2007, Lancaster University, UK Devina Ramduny-Ellis \& Dorothy Rachovides (Editors) latest offerings from Microsoft $\odot$ and Apple $\odot$ be without the all-but-ubiquitous desktop metaphor? Though the desktop is still the primary means by which we interact with computers, the means by which we go about designing interactive technology has changed dramatically, particularly in the last 10 years.

\section{INTERACTION DESIGN AND USER EXPERIENCE}

Interaction design and interest in user experience have emerged as the foci for much of what once would have called itself HCI. Interaction design was first proposed by Moggridge and developed into what we would recognize now by people such as Crampton-Smith at the Royal College of Art. Moggridge describes his early treatment of the subject as Soft-face which comprised " ... a combination between software and userinterface design." [12].

Interaction design which has a distinct product design feel to it, also emphasizes the importance of aesthetics [13], fun [14], pleasure [15], affect [16] and so forth. And all of this is for the current generation of desktop users who most likely do not realize that the desktop is based on a metaphor.

This has been parallel by research into user experience as exemplified by [17], the appearance of new conferences such as DUX and the profession of "user experience designer".

All of which begs the question as to whether cognition remains the most appropriate conceptual basis for the design of interactive systems and devices? Indeed does cognition still have a role in HCI? If so what? For example, how much and what kind of cognition is involved using an iPod, a smart phone or making an e-purchase? These activities might better be described as skilful coping [18]. Perhaps any discussion of cognition should be limited to specialist applications such as the monitoring of complex and safety critical systems?

But, all may not be lost. Our understanding of cognition has evolved dramatically in the last twenty years and is no longer seen as merely a set of processes taking places in an individual's head. Cognition is now recognized to be situated [19], distributed [20][21], embodied [22] and even collective [23][24].

\section{THE THEME OF THIS WORKSHOP}

This workshop is concerned with evaluating whether cognition still has a contribution to make to the current "Second Wave of HCI". It will also consider whether these re-conceptualization of cognition are sufficient to bridge the gap left between the traditional view and the next generation of interactive systems and devices.

\section{REFERENCE}

[1] Carroll, J. (2003) Introduction: Towards a Multidisciplinary Science of Human-Computer interaction. 
In J. Carroll (Ed.) HCI Models, Theories and Frameworks. Morgan Kaufmann.

[2] Dix, A. and Runciman, C. (1985) Abstract models of interactive systems. In P. Johnson and S. Cook (Eds.) People and Computers: Designing The User Interface. Cambridge, UK: Cambridge University Press, 13-22.

[3] Palanque, P. and Paternó, F. (Eds) (1997) Formal Methods in Human Computer Interaction. London: SpringerVerlag.

[4] Payne, S.J. (1991) A Descriptive Study Of Mental Models. Behaviour and Information Technology, 10, 3-21

[5] Payne, S.J. (1992) On Mental Models And Cognitive Artefacts. In Y. Rogers, A. Rutherford and P. Bibby (Eds) Models In The Mind. London: Academic Press.

[6] Hollnagel, E. and Woods, D. (1983) Cognitive Systems Engineering: New Wine In New Bottles. International Journal of Man Machine Studies, 18, 583-600.

[7] John, B.E. and Kieras, D.E. (1996) Using GOMS For User Interface Design And Evaluation: Which Technique? ACM Transactions on Human Computer Interaction, 3(4), 287319.

[8] Vicente, K.J. (1999) Cognitive Work Analysis. Laurence Erlbaum Associates, Mahwah, NJ.

[9] Shackel, B. (1986) Ergonomics in design for usability. Proceedings Of The Second Conference Of The British Computer Society, Human Computer Interaction Specialist Group On People And Computers: Designing For Usability, 44-64.

[10] Watson, M., \& Sanderson, P. (2007). Designing for attention with sound: Challenges and extensions to Ecological Interface Design. Human Factors, 49(2), 331346.

[11] Gardiner, M.M. and Christie, B. (1987) Applying cognitive psychology to user-interface design. John Wiley \& Sons, Inc. New York, NY, USA
[12] Moggridge, B. (2007) Designing Interactions. MIT press.

[13] Petersen, M.G., Iversen, O.S., Krogh, PG and Ludvigsen, M. (2004) Aesthetic Interaction: A Pragmatist's Aesthetics of Interactive Systems. Proceedings of the 2004 Conference on Designing Interactive Systems, Cambridge, MA, $269-276$.

[14] Blythe M.A., Monk A.F., Overbeeke K. and Wright, P.C. (2003) (Eds.) Funology: From Usability to Enjoyment. Kluwer Academic Publishers.

[15] Jordan, P. W. (1998) Human Factors For Pleasure In Product Use. Applied Ergonomics, 29, 25 - 33.

[16] Picard, R.W. (1998) Affective Computing. MIT Press.

[17] McCarthy, J. and Wright, P. (2004) Technology as Experience. MIT Press.

[18] Dreyfus, H.L. (1996) The Current Relevance of MerleauPonty's Phenomenology of Embodiment. Electronic Journal of Analytic Philosophy, 4 (Spring), no pages numbers.

[19] Suchman, L.A. (1987) Plans and Situated Actions: The Problem of Human-Machine Communication. Cambridge, Cambridge University Press.

[20] Hutchins, E. (1995) Cognition in the Wild, MIT Press.

[21] Rogers, Y. and Ellis, J. (1994). Distributed Cognition: an alternative framework for analysing and explaining collaborative working. Journal of Information Technology, 9(2), 119-128.

[22] Dourish, P. (2001) Where the action is. MIT press.

[23] Engeström, Y. (1987) Learning by expanding: An activitytheoretical approach to developmental research, Helsinki: Orienta-Konsultit.

[24] Engeström, Y. (1999) Expansive visibilization of work: an activity theoretic perspective, $C S C W, \mathbf{8 ( 1 - 2 )}$. 